\title{
Effect of heat treatment on quality characteristics and antioxidant activity of Korean traditional actinidia (Actinidia arguta) cultivars puree
}

\author{
Ahna Kim ${ }^{1}$, Sung-Won Kang ${ }^{2}$, Ho-Jin $\mathrm{Heo}^{1}$, Ji-Yeon Chun ${ }^{3}$, Sung-Gil Choi ${ }^{4 *}$ \\ ${ }^{1}$ Division of Applied Life Science, Gyeongsang National University, Gyeongnam 660-701, Korea \\ ${ }^{2}$ S\&T FOODS Co., Ltd., Jinju 660-844, Korea \\ ${ }^{3}$ Department of Food Technology, Sunchon National University, Sunchon 540-742, Korea \\ ${ }^{4}$ Department of Food Science and Technology (Institute of Agriculture and Life Sciences) Gyeongsang National University, \\ Jinju 660-701, Korea
}

\section{열처리 조건이 토종 다래 (Actinidia arguta) 퓨레의 품질 특성 및 항산화활성에 미치는 영향}

\author{
김아나 ${ }^{1} \cdot$ 강성원 $^{2} \cdot$ 허호진 $^{1} \cdot$ 천지연 $^{3} \cdot$ 최성길 ${ }^{4 *}$ \\ ${ }^{1}$ 경상대학교 응용생명과학부 응용생명과학전공, \\ ${ }^{2}$ (주)에스엔티푸드, ${ }^{3}$ 순천대학교 식품공학과, ${ }^{4}$ 경상대학교 식품공학과(농업생명과학연구원)
}

\begin{abstract}
This study investigated the effect of heat treatment conditions on the quality and antioxidant activities of Korean traditional actinidia (Actinidia arguta) cultivars puree. Heat treatment on actinidia puree was conducted at $70 \sim 90{ }^{\circ} \mathrm{C}$ for $1 \mathrm{~min}$ to $5 \mathrm{mins}$, while a control sample of the actinidia puree was prepared without heat treatment. In all the samples, except for the sample treated at $90^{\circ} \mathrm{C}$ for 5 mins, $\mathrm{pH}$ and Brix degree was not dramatically changed. Pulp content decreased with increasing temperature and time. $L$ and the a value of color increased with increasing temperature and time. However, the $b$ value showed a reverse tendency with $L$ and the a value. Viscosity and gumminess increased as heat temperature and time increased, though cohesiveness was not significantly changed depending on temperature and time. Coliform and yeast were not detected on all samples and the number of aerobic bacteria and mold decreased as temperature and time increased. Vitamin $\mathrm{C}$ and total phenolic content of the puree was not changed for 1,3 , and 5 mins at $70^{\circ} \mathrm{C}$ and for 1 and 3 mins at $80^{\circ} \mathrm{C}$, but significantly decreased with increasing time at $90^{\circ} \mathrm{C}$. Furthermore, the antioxidant activities of the puree, such as DPPH radical scavenging activity, ABTS radical scavenging activity, and FRAP (feric reducing antioxidant power) showed a similar tendency with total phenolic content.
\end{abstract}

Key words : Actinidia arguta, heat treatment, quality properties, antioxidant activity

\section{서 론}

*Corresponding author. E-mail : sgchoi@gnu.ac.kr

Phone : 82-55-772-1906, Fax : 82-55-772-1909

Received 16 March 2015; Revised 8 June 2015; Accepted 12 June 2015.

Copyright (c) The Korean Society of Food Preservation. All rights reserved.
토종 다래(Actinidia arguta)는 다래나무과(Actinidiaceae) 에 속하는 낙엽활엽의 다년생 덩굴성 식물로서 내한성과 내병충성이 강한 수종으로 우리나라 산지 전역에 분포 하며 중국과 일본 등에 자생한다(1). 다래는 한겨울에 $-30^{\circ} \mathrm{C}$ 에서 도 자생력이 있어 내한성이 강하며, 참다래(Actinidia deliciosa)는 5 6달의 성숙기간과 달리 다래는 비교적 짧은 3달의 성숙기를 가진다(2). 또한 다래는 과실표면이 부드럽 고 털이 없어 껍질까지 식용이 가능하여 통째로 섭취할 
수 있고, 참다래 $(A$ deliciosa)보다 크기가 작기 때문에 hardy kiwifruit, bower actinidia, baby kiwi, kiwiberry, mini kiwi라 고 불리기도 한다. 현재, 세계적으로 다래의 상업 생산은 증가하고 있으며 최근에 다래의 재배는 뉴질랜드, 미국, 일본, 칠레, 유럽 국가 등에서 널리 이루어지고 있다(2-5).

현재 다래가 "healthy fruit"라고 불리는 것은 다음과 같은 연구가 이를 뒷받침하는 근거가 되고 있다(6). 다래는 폴리 페놀, 비타민 C( 185 mg/100 g fresh weight)가 풍부하여 높은 항산화 활성을 가지는 것으로 알려져 있고 그 외에도 미네랄 중 특히 $\mathrm{P}, \mathrm{Ca}, \mathrm{Fe}, \mathrm{Zn}$ 함량이 높고 상업적으로 얻을 수 있는 과일 중 루테인과 마오이노시틀을 가장 많이 함유 하는 것으로 보고되었다(5,7-12). 또한 다래는 비타민 $\mathrm{E}$ 와 $\mathrm{K}$ 뿐만 아니라 엽산의 좋은 공급원이며 약재로서는 진통제, 이뇨제, 해열제 등으로 이용되고 있고, 건조 질량이 16.6 21.5\%, 가용성 고형물이 8.7 13.6\%, 유기산을 등가물 로 계산한 적정산도의 범위가 $0.8 \sim 1.7 \%$ 으로 보고되었다 (13-18). 다래는 성숙한 딸기, 대황, 파인애플, 배, 바나나, 멜론과 유사한 달콤하고 강한 풍미를 가져 매우 향이 좋아 관능적으로도 우수한 것으로 보고되었다(19). 하지만 토종 다래는 맛이 가장 좋을 때 과실이 쉽게 손상되어 과실의 품질이 급격히 떨어짐으로 상품의 판매 및 유통이 어려우며 저장 및 유통기간이 짧은 문제점이 있다.

현재까지 다래에 관한 주요 연구로는 숙기와 저장에 의 한 hardy $\operatorname{kiwifruit}(A$ arguta 'Ananasnaya')의 이화학적, 관 능적, 영양적 특성(20), $A$ arguta(Sieb. et Zucc.)의 성장, 성숙과 수확 후 반응(2), 저장 동안에 hardy $\operatorname{kiwifruit}(A$ arguta and its hybrid)의 이화학적 품질과 phenolics, vitamin $\mathrm{C}$ 함량의 변화(21), 포장과 저장조건에 따른 hardy kiwifruit ( $A$ arguta 'Ananasnaya')의 수확 후 품질(22), $A$ arguta: 과실과 꽃의 향기성분(23) 등에 관하여 단편적인 연구들이 이루어져 왔고, 기본적인 전처리 가공에 대한 다래의 품질 특성에 관한 연구는 미비한 실정이다. 과채류 가공에 일반 적으로 이용되는 열처리는 원료의 저장수명을 연장하고 식품의 품질을 향상시키기 위하여 사용되고 있으며 이에 관한 많은 연구가 진행되고 있다(24-27). 하지만 열처리 가 공에 따른 다래의 이화학적인 변화와 항산화 활성에 미치는 영향에 관한 연구는 아직 미비한 실정이다.

따라서 본 연구에서는 새로운 임산소득자원으로서의 산 업적 활용가능성을 높이고, 다래를 이용한 각종 가공품 개 발을 위한 기초자료로서 활용하고자 토종 다래 퓨레의 열처 리가 이화학적 성질과 항산화활성에 미치는 영향에 대해 연구하고자 한다.

\section{재료 및 방법}

\section{재료 및 열처리 방법}

본 실험에 사용된 토종 다래(금이농장, 광양)는 10 월에
수확하여 구매한 후 약 $-80^{\circ} \mathrm{C}$ deep freezer에 보관하며 사용 하였다. 퓨레 제조는 동결된 다래를 $4^{\circ} \mathrm{C}$ 에서 해동한 후 믹서 기(HMF-630WG, HANIL ELECTRIC., Wonju, Korea)에 1 분간 마쇄하여 $20 \mathrm{~g}$ 씩 $50 \mathrm{~mL}$ conical tube에 취하였다. 열처 리는 $70,80,90^{\circ} \mathrm{C}$ 에 각각 $1,3,5$ 분씩 항온수조(BS-21, JEIO $\mathrm{TECH}, \mathrm{Kyeonggi,} \mathrm{Korea)}$ )에서 실시한 후 $4^{\circ} \mathrm{C}$ 의 얼음물에 15 분간 냉각시킨 다음 실험에 사용하였으며, 열처리하지 않은 시료를 대조구로 하였다.

\section{$\mathrm{pH}$ 및 당도 측정}

열처리조건에 따른 다래 퓨레의 $\mathrm{pH}$ 및 당도 변화를 살펴 보기 위하여 열처리한 다래 퓨레의 $\mathrm{pH}$ 측정은 $\mathrm{pH}$ meter (735P, Istek, Seoul, Korea)를 사용하였고, 당도는 Abbe refractometer(501-DS, ATAGO Co., Tokyo, Japan)를 사용하 여 측정하였다.

\section{Pulp 함량 분석}

Pulp 함량은 $15^{\circ} \mathrm{C}$ 에서 10 분간 $15,800 \times \mathrm{g}$ 에서 원심분리하 였으며, 다음의 계산식에 의하여 산출하였다(28).

$$
\begin{aligned}
& \text { Pulp } \%=\frac{W_{p}}{W_{s}} \times 100 \\
& W_{p}=\text { pulpweight, } W_{s}=\text { initialsample weight }
\end{aligned}
$$

\section{색도 및 갈변도 측정}

열처리조건에 따른 다래 퓨레의 색 변화를 살펴보기 위 하여 색도는 표준백색판으로 보정된 색차계(Minolta CT-310, Minolta Co., Ltd., Osaka, Japan)를 이용하여 L(lightness), a(redness) 및 b(yellowness) 값을 3회 반복 측정 하였다.

갈변도는 시료 $2 \mathrm{~g}$ 에 증류수 $20 \mathrm{~mL}$ 를 가하고 $10 \%$ trichloroacetic acid $10 \mathrm{~mL}$ 를 가한 다음 상온에서 2시간 방치 한 후 여과하여 $420 \mathrm{~nm}$ 에서 흡광도를 측정하였다(29).

\section{점도 측정}

열처리조건에 따른 다래 퓨레의 점도 변화를 살펴보기 위하여 시료 $10 \mathrm{~g}$ 을 튜브에 담고, $25^{\circ} \mathrm{C}$ 에서 Brookfield viscometer(DV $\Pi+$, Brookfield engineering labs, MA, USA) 를 사용하였으며 SC4-34 spindle을 이용하였고 spindle speed는 $5 \mathrm{rpm}$, spindle increment는 $5 \mathrm{rpm}$ 으로 설정하여 상대점도를 측정하였다.

\section{조직감 측정}

열처리조건에 따른 다래 퓨레의 조직감을 분석하기 위해 texture analyzer(TA-XT Express, Micro stable system, Surrey, England)를 이용해 $25 \mathrm{~mm}$ cylinder probe을 장착하 여 gumminess와 cohesiveness를 측정하였다. 이때 시료 4 
$\mathrm{g}$ 을 지름 $35 \mathrm{~mm}$, 높이 $13 \mathrm{~mm}$ 인 용기에 담은 후 pre-test speed는 $1.0 \mathrm{~mm} / \mathrm{s}$, post-test speed는 $3.0 \mathrm{~mm} / \mathrm{s}$ 으로 하여 조건 당 5 회 측정한 값을 평균하여 나타내었다.

\section{미생물수 측정}

열처리조건에 따른 다래 퓨레의 일반세균은 stomacher $\mathrm{bag}$ 에 시료 $1 \mathrm{~g}$ 과 $0.85 \%$ 멸균생리식염수 $9 \mathrm{~mL}$ 를 가하여 stomacher를 이용하여 120 초간 균질화한 다음 $0.85 \%$ 멸균 생리식염수를 이용하여 단계별로 희석해 시료를 준비하였 다. 단계별 희석액 $1 \mathrm{~mL}$ 을 일반세균은 Petrifilm ${ }^{\mathrm{TM}}$ aerobic count plate(3M Company, St. Paul, MN, USA)를 이용하여 접종한 후 각각 48 시간 동안 $35^{\circ} \mathrm{C}$ 에서 배양 후 $30 ~ 300$ 개 사이의 집락을 계수하여 확인하였고, 검출된 미생물 수는 시료 $1 \mathrm{~g}$ 당 $\log$ colony forming unit(log CFU/g)으로 나타내 었다. 대장균군은 상기의 방법과 동일하게 실시한 후 Petrifilm $^{\mathrm{TM}}$ coliform count plate(3M Company, St. Paul, MN, USA)를 이용하여 24 시간 동안 $35^{\circ} \mathrm{C}$ 에서 배양 후 집락을 계수하여 확인하였다. 효모 및 곰팡이는 상기의 방법과 동 일하게 실시한 후 Petrifilm ${ }^{\mathrm{TM}}$ yeast and mold count plate(3M Company, St. Paul, MN, USA)를 이용하여 120시간 동안 $25^{\circ} \mathrm{C}$ 에서 배양 후 집락을 계수하여 확인하였다.

\section{비타민 C 함량 분석}

비타민 C 함량은 시료를 5 배 희석하여 균질기(D-500, Wiggen Hauser, Berlin, Germany)로 10,000 rpm에서 1분간 균질한 후 여과(No. 2, ADVANTEC, Tokyo, Japan)하여 사 용하였다. 이를 다시 $0.22 \mu \mathrm{m}$ syringe filter로 여과하여 HPLC(Hewlett packard 1100 series, Agilent Technologies, CA, USA)로 분석하였다. Column은 $\mu$-Bondapak $\mathrm{C}_{18}(3.9 \times 30$ $\mathrm{cm}, \mathrm{ID})$ 을 사용하고, 용매와 유속은 각각 $0.05 \mathrm{M} \mathrm{KH}_{2} \mathrm{PO}_{4}$ : acetonitrile(60 : 40)과 $1 \mathrm{~mL} / \mathrm{min}$ 으로 하였으며, $\mathrm{UV}$ 파장과 injection volume은 $254 \mathrm{~nm}$ 와 $20 \mu \mathrm{L}$ 로 하였다(30).

\section{총 페놀 함량 측정}

총 페놀 함량은 $\mathrm{Kim}$ 등(31)이 행한 방법을 변형하여 실험 을 진행하였다. 즉, 시료를 5 배 희석하여 균질기(D-500, Wiggen Hauser)로 $10,000 \mathrm{rpm}$ 에서 1 분간 균질한 후 여과 (No. 2, ADVANTEC)한 여과액 $1 \mathrm{~mL}$ 와 증류수 $9 \mathrm{~mL}$ 을 혼합 후 $1 \mathrm{~mL}$ 의 Folin \& Ciocalteaus' reagent를 첨가 후 실온 암실에서 5 분간 방치한다. 그 후 $7 \%$ sodium carbonate 와 3 차 증류수 $4 \mathrm{~mL}$ 을 첨가한 후 실온 암실에서 2 시간 방치 후 $760 \mathrm{~nm}$ 에서 흡광도를 측정하였다. 표준곡선은 galic acid를 표준물질로 $0.025,0.05,0.1,0.25,0.5,1 \mathrm{mg} / \mathrm{mL}$ 로 제조하여 흡광도를 측정하였다.

\section{항산화활성 측정}

열처리조건에 따른 다래 퓨레의 항산화 활성 측정은 시
료를 5 배 희석하여 균질기(D-500, Wiggen Hauser)로 10,000 $\mathrm{rpm}$ 에서 1 분간 균질한 후 여과(No. 2, ADVANTEC)하여 사용하였다.

$\mathrm{DPPH}$ radical 소거활성은 Choi 등(32)이 행한 방법을 변 형하여 실험을 진행하였다. 즉, $100 \mathrm{~mL}$ 에탄올에 $8 \mathrm{mg}$ 의 $\mathrm{DPPH}$ (2,2 diphenyl-1-picrylhydrazyl)를 용해시켜 여과지로 여과한 후 DPPH 용액 $0.9 \mathrm{~mL}$ 과 시료의 여과액 $0.1 \mathrm{~mL}$ 을 혼합하여 실온 암실에서 30 분간 방치 후 $517 \mathrm{~nm}$ 에서 흡광 도를 측정하였다.

ABTS radical 소거활성은 Foroogh 등(33)의 방법을 참고 및 수정하여 실험을 진행하였다. 즉, $7 \mathrm{mM} \mathrm{ABTS}(2,2-$ azinobis(3-ethylbenzothiazoline-6-sulfonic acid) diammonium salt 와 $2.45 \mathrm{mM}$ potassium persulphate를 혼합 후 실온 암실 에서 16시간 방치 후 $\mathrm{ABTS}(+)$ 용액 $3.9 \mathrm{~mL}$ 와 시료의 여과 액 $0.1 \mathrm{~mL}$ 을 혼합 후 6 분간 실온 암실에 방치 후 $734 \mathrm{~nm}$ 에서 흡광도를 측정하였다.

FRAP(ferric ion reducing antioxidant power) 활성 측정은 Foroogh 등(33)이 행한 방법을 변형하여 실험을 진행하였 다. 즉 $0.3 \mathrm{M}$ sodium acetate buffer(pH 3.6)와 $40 \mathrm{mM} \mathrm{HCl}$ 로 용해시킨 $10 \mathrm{mM}$ tripydyltriazine(TPTZ), $20 \mathrm{mM} \mathrm{FeCl}$. $6 \mathrm{H}_{2} \mathrm{O}$ 을 제조하였다. 미리 제조된 $0.3 \mathrm{M}$ sodium acetate buffer, $10 \mathrm{mM}$ TPTZ, $20 \mathrm{mM} \mathrm{FeCl} \cdot 6 \mathrm{H}_{2} \mathrm{O}$ 을 $10: 1: 1(\mathrm{v} / \mathrm{v} / \mathrm{v})$ 비율로 혼합하여 준비하여 FRAP 용액을 준비하였다. 그 후 시료의 여과액 $50 \mu \mathrm{L}$ 와 FRAP $1.5 \mathrm{~mL}$ 을 혼합 후 실온 암실에서 30 분간 방치한 후 $593 \mathrm{~nm}$ 에서 흡광도를 측정하였 다.

\section{통계처리}

실험결과는 3회 반복실험의 평균 \pm 표준편차로 나타내었 고, 통계처리는 Window 용 SAS(9.4, SAS Institute Inc, Cary, $\mathrm{NC}, \mathrm{USA}$ )을 이용하여 $\mathrm{p}<0.05$ 수준에서 분산분석(analysis of variance)을 하였으며, Duncan의 다중 범위 검정법 (Duncan's multiple range test)으로 유의성을 검증하였다.

\section{결과 및 고찰}

\section{$\mathrm{pH}$, 당도 및 pulp 함량}

열처리 온도 및 시간에 따른 다래 퓨레의 $\mathrm{pH}$, 당도 및 pulp 함량은 Table 1 에 나타내었다. 다래 퓨레의 $\mathrm{pH}$ 는 $90^{\circ} \mathrm{C}$ 5 분을 제외하고는 전체적으로 $3.81 ~ 3.79$ 로 거의 변화가 없 으며, $90^{\circ} \mathrm{C} 5$ 분에서도 3.74 로 다소 낮게 나타났다. AguilarRosas 등(34)은 사과 주스에 HTST-저온살균 $\left(90^{\circ} \mathrm{C}, 30\right.$ 초)했 을 때 무처리 사과 주스에 비해서 $\mathrm{pH}$ 가 다소 낮아졌지만 단지 $\mathrm{pH}$ 3.8 3.9 범위 내에서의 변화이기 때문에 시료의 품질에 큰 영향을 미치지 않는다고 보고되었다. 또한 이러 한 결과는 살균 온도에 따른 오렌지 주스(35). 열처리한 블루베리(36), 고압 이산화탄소와 열처리한 수박주스(37), 
Table 1. The effect of heating temperature and time on $\mathrm{pH}$, Brix degree and pulp content of Actinidia arguta puree

\begin{tabular}{|c|c|c|c|c|}
\hline $\begin{array}{l}\text { Temperature } \\
\left({ }^{\circ} \mathrm{C}\right)\end{array}$ & $\begin{array}{l}\text { Time } \\
(\mathrm{min})\end{array}$ & $\mathrm{pH}$ & ${ }^{\circ}$ Brix & Pulp content (\%) \\
\hline \multicolumn{2}{|c|}{ Control } & $3.81 \pm 0.02^{\mathrm{al})}$ & $11.43 \pm 0.15^{\mathrm{a}}$ & $53.68 \pm 2.76^{\mathrm{a}}$ \\
\hline \multirow{3}{*}{70} & 1 & $3.80 \pm 0.01^{\mathrm{ab}}$ & $11.23 \pm 0.21^{b}$ & $54.20 \pm 3.81^{\mathrm{a}}$ \\
\hline & 3 & $3.80 \pm 0.01^{\mathrm{ab}}$ & $11.27 \pm 0.15^{b}$ & $52.82 \pm 1.70^{\mathrm{ab}}$ \\
\hline & 5 & $3.80 \pm 0.01^{\mathrm{bc}}$ & $11.23 \pm 0.15^{\mathrm{b}}$ & $48.44 \pm 2.76^{\mathrm{c}}$ \\
\hline \multirow{3}{*}{80} & 1 & $3.80 \pm 0.01^{b c}$ & $11.20 \pm 0.20^{b}$ & $49.82 \pm 0.80^{\mathrm{bc}}$ \\
\hline & 3 & $3.80 \pm 0.00^{b c}$ & $11.23 \pm 0.15^{b}$ & $46.27 \pm 2.97^{\mathrm{c}}$ \\
\hline & 5 & $3.79 \pm 0.01^{\mathrm{bc}}$ & $11.17 \pm 0.06^{b}$ & $36.99 \pm 1.05^{\mathrm{d}}$ \\
\hline \multirow{3}{*}{90} & 1 & $3.79 \pm 0.01^{\mathrm{bc}}$ & $11.23 \pm 0.15^{b}$ & $49.14 \pm 1.51^{c}$ \\
\hline & 3 & $3.79 \pm 0.01^{b c}$ & $11.13 \pm 0.06^{b}$ & $39.20 \pm 1.60^{\mathrm{d}}$ \\
\hline & 5 & $3.74 \pm 0.00^{\mathrm{d}}$ & $10.23 \pm 0.06^{c}$ & $39.37 \pm 2.87^{\mathrm{d}}$ \\
\hline
\end{tabular}

${ }^{11}$ Means \pm SD ( $\mathrm{n}=3$ ) in a row followed by same letter are not significantly different by Duncan's multiple range test $(\mathrm{p}<0.05)$.

초고압과 가열살균 처리한 파인애플 주스(38)의 연구결과 와 유사하다.

먼저 당도의 경우 대조군은 $11.43^{\circ} \mathrm{Brix}$ 였고, 열처리에 따라 전체적으로 $11.27 \sim 10.23^{\circ} \mathrm{Brix}$ 로 나타났다. $90^{\circ} \mathrm{C}$ 에서 5 분간 처리했을 때 $10.23^{\circ} \mathrm{Brix}$ 로 다소 감소한 것을 제외하 고는 열처리에 따른 큰 변화는 없었다. Rossi 등(36)의 연구 에서 블루베리를 3 분간 steam blanching하였을 때, 무처리 블루베리 주스의 당도는 $10.33^{\circ} \mathrm{Brix}$, 열처리 블루베리 주스 의 당도는 $10.13^{\circ} \mathrm{Brix}$ 으로 다소 낮아지는 것으로 나타났다.

열처리 온도 및 시간에 따른 시료의 pulp 함량은 처리 온도가 증가하고 처리 시간이 길어짐에 따라서 유의적으로 감소하였다. 대조구는 $53.68 \%$ 였고, $70^{\circ} \mathrm{C} 5$ 분 처리 시 $48.44 \%$ 로 감소하였으며, $80,90^{\circ} \mathrm{C}$ 에서는 $39.37 \sim 39.20 \%$ 로 감소하였다. 결과적으로 다래 퓨레의 열처리 조건에 따라
서 $\mathrm{pH}$, 당도, pulp 함량을 측정하였을 때 전체적으로 $90^{\circ} \mathrm{C}$ 에 서 5 분간 처리 시 다래 퓨레의 품질이 상대적으로 저하되었 지만, 70 80 $\mathrm{C}$ 에서는 비교적 다래 퓨레의 품질이 잘 유지되 는 것을 확인할 수 있었다.

\section{색도 및 갈변도}

저장이 필요한 신선한 농산물은 가공, 저장 중 주로 효소 에 의해서 품질이 저하되는데, 특히 peroxidase라는 효소는 많은 식물에 광범위하게 분포되어 있는 효소로서 식물성 식품을 변색시키고 또한 향미 손상, 영양소 파괴를 일으킨 다고 보고되고 있다 $(39,40)$. 그러므로 열처리를 통해서 동 결 전에 저장이 필요한 채소, 과일, 버섯류는 효소로 인한 변질을 막는 것이 일반적이다(41). 열처리 온도 및 시간에 따른 다래 퓨레의 색도를 측정하였고 그 결과는 Table 2 와 같다. 수치가 양수에 가깝게 높아질수록 녹색도가 낮아짐 을 나타내는 $\mathrm{a}$ 값은 대조군이 -11.13 이었고, 열처리에 따라 - 10.30 -9.26으로 증가하였고, 이는 Fig. 1의 외관의 변화 와 유사한 경향을 보인 것이며, 열처리가 다래 퓨레가 지니 는 녹색도에 큰 영향을 미치는 것으로 사료된다. Kweon 등(42)에 의하면 사과의 a 값은 처리 전이 21.1 이었으나 $38^{\circ} \mathrm{C}$ 처리구는 $22.1,46^{\circ} \mathrm{C}$ 처리구는 23.5 로서 다소 높아지는 경향이었다. 이와 같은 결과는 열처리는 처리전보다 적색 이 향상되는 경향이었지만 탁한 적색으로 된 것을 의미하고 있어 과실품질이 향상된 결과는 아니라고 판단된다고 보고 하였다. Ahmed 등(43)은 $\mathrm{L}, \mathrm{a}, \mathrm{b}$ 값 중 $\mathrm{a}$ 값은 열처리 공정 중 녹색 고추 퓨레의 색변화를 가장 잘 나타낼 수 있는 지표의 역할을 한다고 보고하였다. 또한 Song 등(44)에 의 하면 풋콩과 풋콩의 꼬투리를 $80,90,100^{\circ} \mathrm{C}$ 에서 열처리했 을 때의 $\mathrm{a}$ 값은 처리 온도가 높을수록 더 급격히 증가하는 것으로 나타났고, $\mathrm{L}$ 값과 $\mathrm{b}$ 값은 $\mathrm{a}$ 값만큼 열처리에 따라서 유의적인 차이를 보이지 않는 것으로 보고하였다. $\mathrm{L}$ 값은

Table 2. The effect of heating temperature and time on color value and browning degree of Actinidia arguta puree

\begin{tabular}{|c|c|c|c|c|c|}
\hline \multirow{2}{*}{ Temperature $\left({ }^{\circ} \mathrm{C}\right)$} & \multirow{2}{*}{$\begin{array}{l}\text { Time } \\
(\mathrm{min})\end{array}$} & \multicolumn{3}{|c|}{ Color value } & \multirow{2}{*}{ Browning degree } \\
\hline & & $\mathrm{L}$ & $\mathrm{a}$ & $\mathrm{b}$ & \\
\hline \multicolumn{2}{|l|}{ Control } & $52.08 \pm 0.31^{\mathrm{cd} l)}$ & $-11.13 \pm 0.11^{\mathrm{e}}$ & $19.33 \pm 0.55^{\mathrm{a}}$ & $2.96 \pm 0.17^{\mathrm{c}}$ \\
\hline \multirow{3}{*}{70} & 1 & $51.80 \pm 0.48^{\mathrm{e}}$ & $-10.30 \pm 0.42^{\mathrm{cd}}$ & $18.37 \pm 0.61^{b c}$ & $3.04 \pm 0.02^{b c}$ \\
\hline & 3 & $52.91 \pm 0.24^{b}$ & $-10.09 \pm 0.03^{\mathrm{bc}}$ & $18.23 \pm 0.14^{\mathrm{bc}}$ & $3.22 \pm 0.10^{\mathrm{a}}$ \\
\hline & 5 & $52.94 \pm 0.34^{\mathrm{b}}$ & $-9.65 \pm 0.13^{\mathrm{ab}}$ & $18.07 \pm 0.08^{\mathrm{bc}}$ & $3.29 \pm 0.09^{\mathrm{a}}$ \\
\hline \multirow{3}{*}{80} & 1 & $52.02 \pm 0.25^{\mathrm{de}}$ & $-10.24 \pm 0.46^{\mathrm{bc}}$ & $17.67 \pm 0.36^{c}$ & $3.08 \pm 0.12^{b}$ \\
\hline & 3 & $52.55 \pm 0.29^{\mathrm{bc}}$ & $-10.00 \pm 0.15^{\mathrm{bc}}$ & $18.32 \pm 0.15^{\mathrm{bc}}$ & $3.30 \pm 0.06^{\mathrm{a}}$ \\
\hline & 5 & $53.67 \pm 0.21^{a}$ & $-9.26 \pm 0.10^{\mathrm{a}}$ & $18.28 \pm 0.11^{\mathrm{bc}}$ & $3.27 \pm 0.04^{\mathrm{a}}$ \\
\hline \multirow{3}{*}{90} & 1 & $51.86 \pm 0.39^{\mathrm{e}}$ & $-10.82 \pm 0.32^{\mathrm{de}}$ & $17.91 \pm 0.67^{\mathrm{c}}$ & $3.00 \pm 0.17^{\mathrm{bc}}$ \\
\hline & 3 & $52.44 \pm 0.30^{\text {bcd }}$ & $-10.20 \pm 0.12^{\mathrm{bc}}$ & $18.86 \pm 0.62^{\mathrm{ab}}$ & $3.26 \pm 0.09^{\mathrm{a}}$ \\
\hline & 5 & $52.66 \pm 0.20^{\mathrm{b}}$ & $-9.39 \pm 0.69^{\mathrm{a}}$ & $19.60 \pm 0.29^{\mathrm{a}}$ & $3.31 \pm 0.10^{\mathrm{a}}$ \\
\hline
\end{tabular}

${ }^{1)}$ Means \pm SD $(n=3)$ in a row followed by same letter are not significantly different by Duncan's multiple range test $(\mathrm{p}<0.05)$. 

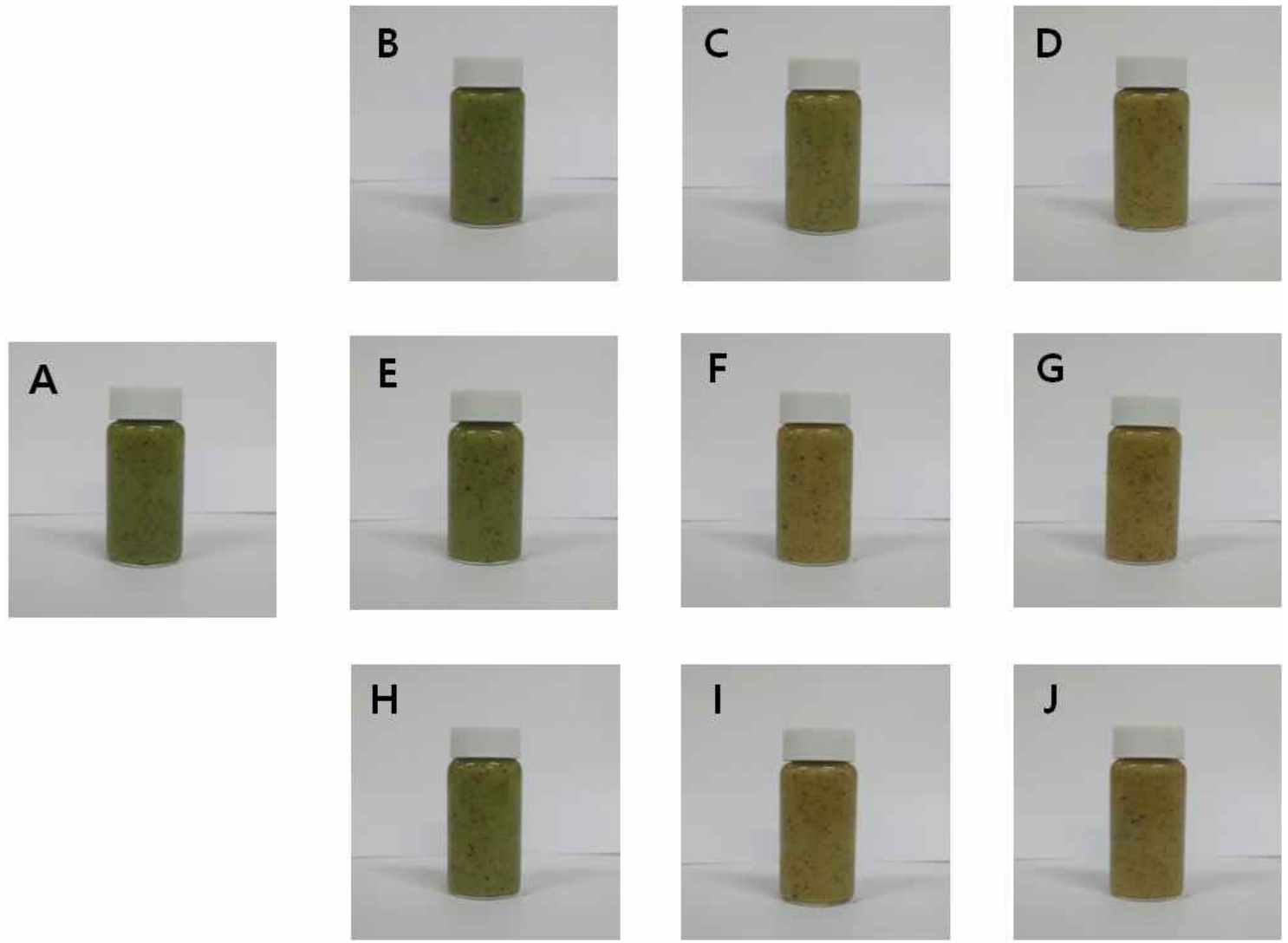

Fig. 1. The effect of heating temperature and time on the appearance of Actinidia arguta puree A, control; B, $70^{\circ} \mathrm{C}$ for $1 \mathrm{~min} ; \mathrm{C}, 70^{\circ} \mathrm{C}$ for $3 \mathrm{~min}$;, $70^{\circ} \mathrm{C}$ for $5 \mathrm{~min}$; E, $80^{\circ} \mathrm{C}$ for $1 \mathrm{~min} ; \mathrm{F}, 80^{\circ} \mathrm{C}$ for $3 \mathrm{~min} ; \mathrm{G}, 80^{\circ} \mathrm{C}$ for $5 \mathrm{~min}$; $\mathrm{H}, 90^{\circ} \mathrm{C}$ for $1 \mathrm{~min}$;, $90^{\circ} \mathrm{C}$ for $3 \mathrm{~min} ; \mathrm{J}, 90^{\circ} \mathrm{C}$ for $5 \mathrm{~min}$.

전체적으로 53.67 51.80로 나타났으며, 모든 열처리 온도 에서 1 분간 처리 시 대조구에 비해 다소 감소한 후 처리 시간이 길어질수록 증가하였다. 이는 $\mathrm{pH}$ 가 감소하면 브로 콜리의 세포 구조를 파괴시킴으로써 엽록체 내의 chlorophyll을 방출시켜 갈변을 촉진시킨다고 보고하였다. 따라서 1 분 열처리는 chlorophyll의 방출되었으나 pheophytins 으로의 변형은 일어나지 않아 대조구에 비해 색이 진해졌 고, 이에 따라서 $\mathrm{L}$ 값이 감소된 것이라 사료된다(45). 또한 blanching 처리는 일반적으로 세포를 손상시키고 세포의 미세구조를 파괴시켜 세포내의 존재하는 공기를 제거함으 로써 색상을 뚜렷하게 한다고 보고되었다(46). Beirão-daCosta 등(47)은 키위를 열처리했을 때 처리 온도가 높을수 록 $\mathrm{L}$ 값이 감소한다고 보고하였고, 이는 다래 퓨레를 70 , $80,90^{\circ} \mathrm{C}$ 에서 열처리한 본 실험과는 달리 키위 슬라이스를 $10 ~ 50^{\circ} \mathrm{C}$ 에서 처리하였으므로 다른 색 변화의 경향을 보인 것으로 생각된다. Lee 등(48)은 참다래주스를 $65,75,85^{\circ} \mathrm{C}$ 에서 15 초간 열처리 시 $\mathrm{L}$ 값의 유의적인 차이가 없었고, 이는 본 실험의 열처리 시간보다 짧았고 전체 중량에서 $60 \%$ 가 생수였으므로 $\mathrm{L}$ 값의 뚜렷한 변화가 나타나지 않은 것으로 사료된다. $\mathrm{b}$ 값의 경우 17.67 19.60의 범위로 나타났 으며, 열처리에 따른 뚜렷한 경향이 나타나지 않았다.
Ahmed 등(43)의 연구에서 $60^{\circ} \mathrm{C}$ 에서 열처리 시간에 따른 녹색 고추 퓨레의 색도 중 $\mathrm{b}$ 값의 $\mathrm{r}$ 스퀘어가 가장 낮아 가장 적은 영향을 미치는 것으로 나타났다. 또한 Koca과 Karadeniz(49)는 $\mathrm{pH}$ 에 따른 데친 완두콩의 chlorophyll 감소 와 색의 손실에 미치는 영향에 대한 연구에서 더 높은 $\mathrm{pH}$ 에 서 녹색이 잘 유지된다고 보고하였다.

열처리 온도 및 시간에 따른 시료의 갈변도의 결과는 Table 2 와 같다. 열처리온도가 증가하고 열처리 시간이 길 어짐에 따라서 갈변도가 유의적으로 증가하는 것으로 나타 났으며, 대조구는 2.96로 가장 낮은 갈변도를 나타냈고, 9 $0^{\circ} \mathrm{C}$ 에서 5 분간 처리한 다래 퓨레는 3.31 로 가장 높은 갈변도 를 보였다. 이러한 갈변도의 경향은 $\mathrm{a}$ 값의 변화와 유사한 것으로 나타나 $\mathrm{a}$ 값이 다래 퓨레의 갈변도를 가장 잘 나타낼 수 있는 지표라고 판단된다. Lee 등(48)의 연구에서는 참다 래 주스를 $65,75,85^{\circ} \mathrm{C}$ 에서 15 초 동안 가열 살균하였을 때 살균온도가 높아질수록 갈변도가 증가하는 것으로 나타 나 본 실험과 유사한 결과를 나타내었으며, 이러한 결과는 가열 살균하면서 색소물질의 하나인 안토시아닌이 열과 반응하여 갈색화 물질을 형성하며, 가열살균에 의해 분리 된 참다래 주스 내 vitamin $\mathrm{C}$ 분자들과 안토시아닌 색소 
물질이 결합하여 갈변 현상을 일으키기 때문으로 사료된다 고 보고하였다. 또한 이와 같이 열처리에 따라서 갈변이 진행되는 것은 선명한 녹색인 chlorophylls에서 흐린 올리브 갈색인 pheophytins으로 변하기 때문이라고 보고했으며, 열 처리 동안의 chlorophylls에서 pheophytins으로의 변화의 주 요한 요인은 열처리 시간과 온도이므로 짧은 처리 시간동안 높은 온도에서 처리하는 것은 더 짧은 시간동안 더 낮은 온도에서 처리하는 것보다 녹색을 유지하는데 효과적이라 고 보고되었다(50-53). 결과적으로 본 실험에서는 처리 온 도가 증가하고 처리 시간이 길어질수록 $\mathrm{a}$ 값과 갈변도는 증가하는 경향으로 나타났으며, 대조구보다 더 선명한 색 을 띄며 갈변도의 변화가 적은 $70^{\circ} \mathrm{C}$ 에서 1 분간 열처리가 다래 퓨레의 외관, 색도 및 갈변도에서 가장 효과적인 열처 리라고 사료된다.

\section{점도 및 조직감}

열처리 온도 및 시간에 따른 다래 퓨레의 점도를 측정한 결과는 Fig. 2에 나타내었다. 대조구의 점도는 $4129.12 \mathrm{cps}$ 였고, $1,3,5$ 분 열처리 동안 $70^{\circ} \mathrm{C}$ 에서 $4137.11 ~ 5368.85 \mathrm{cps}$, $80^{\circ} \mathrm{C}$ 에서 $4371.07 \sim 6086.70 \mathrm{cps}, 90^{\circ} \mathrm{C}$ 에서 $5178.89 \sim 6558.60$ $\mathrm{cps}$ 로 나타나 모든 온도에서 열처리 시간이 경과함에 따라 점도가 증가하는 경향을 보였다. 또한 열처리 온도가 높아 질수록 점도가 증가하는 경향을 보여 열처리 시간 및 온도 가 모두 다래 퓨레의 점도 변화에 영향을 미치는 것으로 나타났다. Tárrega 등(54)은 겔화 현상은 더 단단하고 불규 칙적인 구조를 형성하며, 감을 열처리한 후 냉각하였을 때 저장 탄성률이 증가하는 것으로 나타났으며, $\mathrm{pH}$ 5.9보다 $\mathrm{pH}$ 4.4에서 형성된 겔이 더 단단한 것으로 나타났다고 보고 하였다. 또한 일반적으로 $\mathrm{pH}$ 3이하로의 산성화는 겔 형성 을 촉진시키며, 고온의 용액을 냉각하면 자발적으로 겔화 가 일어난다고 보고하였다(55,56). Galanakis 등(57)은 열처

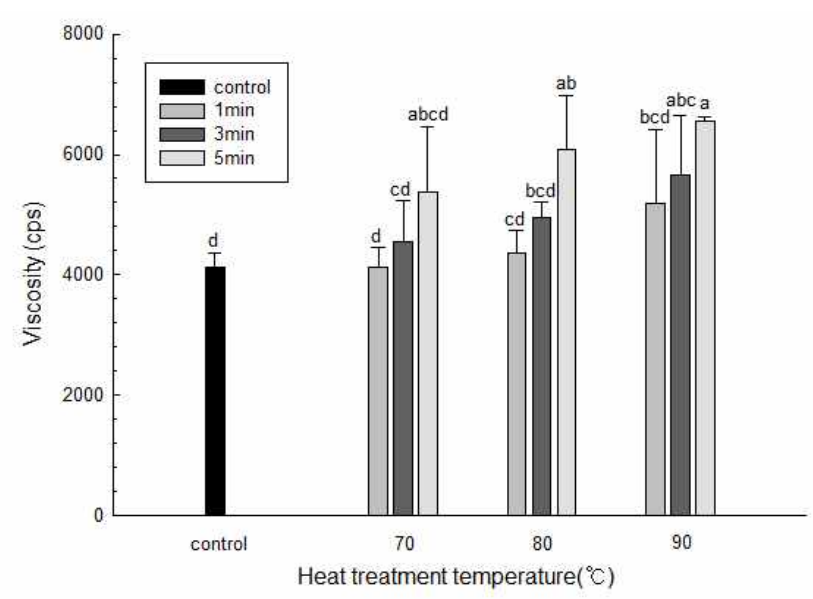

Fig. 2. The effect of heating temperature and time on the viscosity of Actinidia arguta puree

Means \pm SD $(\mathrm{n}=3$ ) in a row followed by same letter are not significantly different by Duncan's multiple range test $(\mathrm{p}<0.05)$.
리는 올리브의 펙틴이 겔 형성을 초래하고, 겔의 특성은 처리 온도에 영향을 미칠 뿐만 아니라 $60^{\circ} \mathrm{C}$ 보다 $80^{\circ} \mathrm{C}$ 에서 처리된 시료의 펙틴이 더 단단한 겔을 형성하는 것으로 보고하였다. 또한 펙틴질의 분해에 기인하는 pectinesterase 와 polygalacturonase는 최종 제품의 점도를 감소시키기 때 문에 주로 열처리에 의해서 불활성화 시킨다고 보고하였다 (58).

열처리 온도 및 시간에 따른 시료의 조직감을 측정한 결과는 Table 3 에서 보는 바와 같이 다래 퓨레의 열처리 온도가 높아지고 시간이 증가할수록 cohesiveness는 뚜렷한 경향을 보이지 않았고 gumminess는 증가하는 경향을 나타 내어 이는 열처리 조건에 따른 다래 퓨레의 점도의 결과와 유사한 경향인 것으로 나타났다. 따라서 열처리 중 겔 형성 은 다래 퓨레의 가공 적성에 알맞지 않으며 퓨레로써의 식감에도 좋지 않은 영향을 미치기 때문에 높은 온도에서 장시간 다래 퓨레를 열처리하는 것은 피해야 할 것으로 사료된다.

Table 3. The effect of heating temperature and time on texture of Actinidia arguta puree as affected by heating temperature and time

\begin{tabular}{cccc}
\hline $\begin{array}{c}\text { Temperature } \\
\left({ }^{\circ} \mathrm{C}\right)\end{array}$ & $\begin{array}{c}\text { Time } \\
(\mathrm{min})\end{array}$ & Gumminess & Cohesiveness \\
\hline Control & & $26.57 \pm 2.16^{\mathrm{bl})}$ & $0.72 \pm 0.04^{\mathrm{b}}$ \\
\hline \multirow{2}{*}{70} & 1 & $20.60 \pm 1.02^{\mathrm{c}}$ & $0.73 \pm 0.01^{\mathrm{ab}}$ \\
& 3 & $26.28 \pm 1.47^{\mathrm{b}}$ & $0.73 \pm 0.02^{\mathrm{ab}}$ \\
& 5 & $23.40 \pm 0.52^{\mathrm{bc}}$ & $0.72 \pm 0.02^{\mathrm{b}}$ \\
\hline \multirow{2}{*}{80} & 1 & $26.89 \pm 0.89^{\mathrm{b}}$ & $0.73 \pm 0.03^{\mathrm{ab}}$ \\
& 3 & $25.47 \pm 2.66^{\mathrm{b}}$ & $0.72 \pm 0.03^{\mathrm{b}}$ \\
& 5 & $43.07 \pm 6.51^{\mathrm{a}}$ & $0.72 \pm 0.03^{\mathrm{b}}$ \\
\hline \multirow{3}{*}{90} & 1 & $26.75 \pm 2.19^{\mathrm{b}}$ & $0.74 \pm 0.02^{\mathrm{ab}}$ \\
& 3 & $27.17 \pm 1.95^{\mathrm{b}}$ & $0.74 \pm 0.03^{\mathrm{ab}}$ \\
& 5 & $45.11 \pm 1.57^{\mathrm{a}}$ & $0.76 \pm 0.01^{\mathrm{a}}$ \\
\hline
\end{tabular}

${ }^{1)}$ Means \pm SD ( $(n=3)$ in a row followed by same letter are not significantly different by Duncan's multiple range test $(\mathrm{p}<0.05)$.

미생물 수

열처리 온도 및 시간에 따른 일반세균, 대장균군, 효모 및 곰팡이 균수의 변화를 측정하여 Table 4에 나타내었다. 먼저, 대장균군과 효모의 경우는 다래 대조군의 시료에서 검출되지 않았으며, 모든 처리군 시료에서도 역시 검출되 지 않았다. 먼저 일반세균의 경우 대조구은 $2.06 \log \mathrm{CFU} / \mathrm{g}$ 수준이었으나 $1,3,5$ 분 동안 열처리 시 $70^{\circ} \mathrm{C}$ 의 경우 2.06 1.60 $\log \mathrm{CFU} / \mathrm{g}$ 의 범위였고, $80^{\circ} \mathrm{C}$ 에서는 $1.91 \sim 1.28 \mathrm{log}$ $\mathrm{CFU} / \mathrm{g}, 90^{\circ} \mathrm{C}$ 에서는 $1.71 \sim 1.56 \log \mathrm{CFU} / \mathrm{g}$ 으로 열처리에 따 라 점차 감소하는 경향을 보였다.

그리고 곰팡이의 경우 대조군에서는 $2.06 \log \mathrm{CFU} / \mathrm{g}$ 으로 나타났고, $70^{\circ} \mathrm{C}$ 에서 모든 처리 시간과 $80^{\circ} \mathrm{C}$ 에서 1,3 분 처리 
시 2.00 1.80 $\log \mathrm{CFU} / \mathrm{g}$ 의 범위로 나타나 대조구와 크게 변화가 없었지만, $80^{\circ} \mathrm{C}$ 와 $90^{\circ} \mathrm{C}$ 에서 5 분간 처리 시에는 각각 $1.36 \log \mathrm{CFU} / \mathrm{g}, 0.80 \log \mathrm{CFU} / \mathrm{g}$ 로 매우 크게 감소하였다. $\mathrm{Kim}$ 등(59)은 국내산 배추 종자를 열처리 온도와 시간에 따른 총 호기성 세균을 조사하였을 때 열처리 온도 및 시간 에 따라 대조군에 비해 유의적으로 감소하는 경향을 보였다 고 보고하였다. 또한 Lee와 Jun 등(60)은 적무 종자를 60 9 $0{ }^{\circ} \mathrm{C}$ 에서 열처리 시 미생물 제어효과는 온도변화에 따른 유의적인 차이를 나타내었다고 보고하였다. 이와 같은 수 확 후 열처리는 병원균을 성공적으로 저감하는 데 이용되며 몇몇 과일의 저장 동안의 품질을 유지하기 위해서 사용된다 고 보고하였다(61,62). Vicente 등(63)과 Garc'1a 등(64)은 딸기를 열처리했을 때 병원균을 제어할 수 있을 뿐만 아니 라 저장 동안 품질의 보존에도 효과적이라고 보고하였다.

결과적으로 열처리 시간 및 온도가 다래 퓨레의 일반세 균과 곰팡이의 균수의 변화에 영향을 미치며 전체적으로 열처리에 의해 감소되는 것으로 나타났고, 특히 $80^{\circ} \mathrm{C}$ 와 9 $0^{\circ} \mathrm{C}$ 에서 5 분간 열처리하는 것이 다래 퓨레의 미생물 저감화 에 매우 효과적인 것으로 사료된다. 또한, 다래 퓨레의 가공 시 품질요소 변화와 고려하여 적합한 열처리 살균 시간이 결정되어야 할 것으로 판단된다.

\section{비타민 C 및 총 페놀 함량}

과일은 페놀물질과 비타민 $\mathrm{C}$ 의 좋은 공급원이지만, 가공 공정 중 열과 산화의 영향으로 인하여 그 함량이 감소하여 품질이 저하될 수 있다. 따라서 본 연구에서는 열처리 온도 및 시간에 따른 다래 퓨레의 비타민 $\mathrm{C}$ 와 총 페놀의 함량을 측정하여 각각 Fig. 3,4 에 나타내었다. 먼저, 비타민 C의 경우 대조구는 $121.33 \mathrm{mg} / 100 \mathrm{~g}$ 으로 나타났고, $1,3,5$ 분 열처리 시 $70^{\circ} \mathrm{C}$ 에서는 각각 $122.54,129.00,127.64 \mathrm{mg} / 100$ $\mathrm{g}$ 로 거의 변화가 없었다. $80^{\circ} \mathrm{C}$ 에서도 1,3 분에서는 거의 변화가 없었지만 5 분 처리 시 $82.47 \mathrm{mg} / 100 \mathrm{~g}$ 으로 다소 감소하였다. 또한 $90^{\circ} \mathrm{C}$ 에서는 1,3 분 처리 시 $107.59 \mathrm{mg} / 100$ $\mathrm{g}, 92.34 \mathrm{mg} / 100 \mathrm{~g}$ 으로 다소 감소하였고, 특히 5 분 처리 시 $22.28 \mathrm{mg} / 100 \mathrm{~g}$ 으로 크게 감소하였다. Yeom 등(65)은 비타민 C는 일반적으로 열에 민감한 영양소라고 보고하였 으며, Smooth 등(66)은 오렌지 주스의 ascorbic acid 손실이 살균온도가 증가할수록 증가한다고 보고하였고, Lee 등 (48)은 참다래 주스를 65,75 및 $85^{\circ}$ C에서 15 초 동안 열처리 후 비타민 C의 함량은 $0.26,0.21$ 및 $0.20 \mathrm{mg} / \mathrm{mL}$ 로 차이를 나타내었고, 이는 $65^{\circ} \mathrm{C}$ 이상에서 열처리 시 그 감소 정도가 큰 것으로 보고하여 본 실험과 유사한 결과임을 알 수 있었 으며, 이는 ascorbic acid가 가열살균에 의해 산화반응이 나타나기 때문이라고 보고하였다. 또한 Jang 등(35)은 오렌 지 주스를 $75,85,95^{\circ} \mathrm{C}$ 에서 각각 15 초 살균하였을 때 $75^{\circ} \mathrm{C}$ 살균온도에서 온도 증가에 따른 비타민 $\mathrm{C}$ 함량의 저장기간 에 따른 변화가 가장 우수하였으나 그 차이는 미미한 것으 로 보고하였다. Sánchez-Moreno 등(67)은 토마토 퓨레를 $70^{\circ} \mathrm{C}$ 에서 30 초, $90^{\circ} \mathrm{C}$ 에서 1 분 동안 열처리 시 대조구에 비해 유의적으로 비타민 $\mathrm{C}$ 의 함량이 낮아졌지만 처리구간 유의 적인 차이는 나타나지 않았다고 보고하였다. 또한 살균 저 장한 오렌지 주스와 같은 과실 주스의 경우 비타민 $\mathrm{C}$ 함량 의 손실은 flavor와 색 변화의 원인이 된다고 보고되고 있고 이는 본 실험의 결과와 일치하는 것을 알 수 있었으며, 살균 된 과실의 열처리 조건에 의한 품질저하 인자로서 중요한 영향을 미치는 것으로 생각된다(68-70).

열처리 온도 및 시간에 따른 다래 퓨레의 총 페놀 함량의 경우 대조구는 $94.29 \mathrm{mg} \mathrm{GAE} / 100 \mathrm{~g}$ 였으며, $1,3,5$ 분 열처리 시 $70^{\circ} \mathrm{C}$ 에서는 각각 $90.75,89.71,87.75 \mathrm{mg} \mathrm{GAE} / 100 \mathrm{~g}$ 로 거의 변화가 없었다. $80^{\circ} \mathrm{C}$ 에서도 1,3 분 처리 시 거의 변화가

Table 4. The effect of heating temperature and time on the number of aerobic bacteria, coliform, yeast, and mold (log CFU/g) on Actinidia arguta puree

\begin{tabular}{|c|c|c|c|c|c|}
\hline Temperature $\left({ }^{\circ} \mathrm{C}\right)$ & $\begin{array}{l}\text { Time } \\
(\mathrm{min})\end{array}$ & Aerobic bacteria & Coliform & Yeast & Mold \\
\hline Control & & $2.06 \pm 0.08^{\mathrm{al})}$ & $\mathrm{ND}^{2)}$ & $\mathrm{ND}$ & $2.06 \pm 0.07^{\mathrm{a}}$ \\
\hline \multirow{3}{*}{70} & 1 & $2.06 \pm 0.06^{\mathrm{a}}$ & $\mathrm{ND}$ & $\mathrm{ND}$ & $1.96 \pm 0.04^{b}$ \\
\hline & 3 & $1.86 \pm 0.02^{\mathrm{ab}}$ & $\mathrm{ND}$ & $\mathrm{ND}$ & $1.92 \pm 0.03^{\mathrm{b}}$ \\
\hline & 5 & $1.60 \pm 0.04^{b c}$ & $\mathrm{ND}$ & $\mathrm{ND}$ & $1.80 \pm 0.04^{c}$ \\
\hline \multirow{3}{*}{80} & 1 & $1.91 \pm 0.06^{\mathrm{ab}}$ & $\mathrm{ND}$ & $\mathrm{ND}$ & $2.00 \pm 0.05^{\mathrm{ab}}$ \\
\hline & 3 & $1.76 \pm 0.06^{\mathrm{abc}}$ & ND & $\mathrm{ND}$ & $1.97 \pm 0.06^{b}$ \\
\hline & 5 & $1.28 \pm 0.10^{\mathrm{d}}$ & ND & $\mathrm{ND}$ & $1.36 \pm 0.04^{\mathrm{e}}$ \\
\hline \multirow{3}{*}{90} & 1 & $1.71 \pm 0.04^{\mathrm{bc}}$ & $\mathrm{ND}$ & $\mathrm{ND}$ & $1.57 \pm 0.04^{d}$ \\
\hline & 3 & $1.47 \pm 0.08^{\mathrm{cd}}$ & ND & $\mathrm{ND}$ & $1.66 \pm 0.03^{\mathrm{d}}$ \\
\hline & 5 & $1.56 \pm 0.49^{\mathrm{e}}$ & $\mathrm{ND}$ & $\mathrm{ND}$ & $0.80 \pm 0.08^{f}$ \\
\hline
\end{tabular}

\footnotetext{
${ }^{1)}$ Means $\pm \mathrm{SD}(\mathrm{n}=3)$ in a row followed by same letter are not significantly different by Duncan's multiple range test $(\mathrm{p}<0.05)$.
}

${ }^{2)} \mathrm{ND}:$ not detected. 


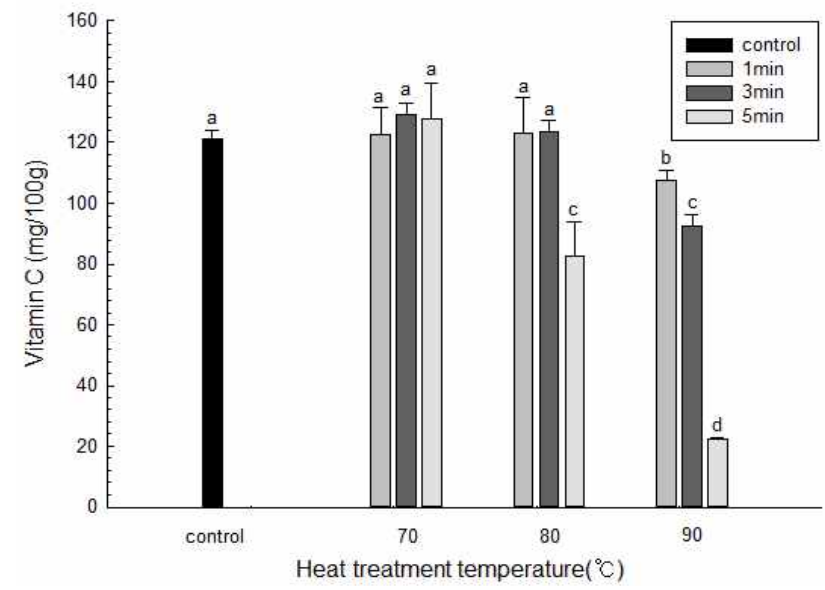

Fig. 3. The effect of heating temperature and time on the Vitamin C content of Actinidia arguta puree

Means \pm SD ( $n=3$ ) in a row followed by same letter are not significantly different by Duncan's multiple range test $(\mathrm{p}<0.05)$.

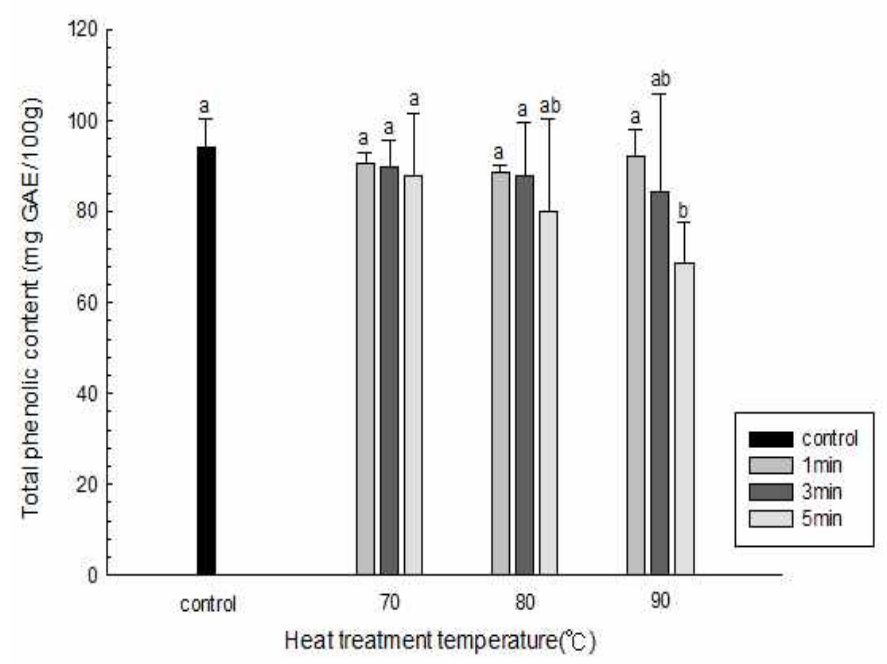

Fig. 4. The effect of heating temperature and time on the total phenolic content of Actinidia arguta puree

Means $\pm \mathrm{SD}(\mathrm{n}=3)$ in a row followed by same letter are not significantly different by Duncan's multiple range test $(\mathrm{p}<0.05)$.

없었지만 5 분에서는 $80.13 \mathrm{mg} \mathrm{GAE} / 100 \mathrm{~g}$ 으로 다소 감소하 였다. 또한 $90^{\circ} \mathrm{C}$ 에서는 1 분에서 거의 변화가 없었고, 3,5 분 에서는 각각 $84.38,68.67 \mathrm{mg} \mathrm{GAE} / 100 \mathrm{~g}$ 으로 감소하였다. 결과적으로 총 페놀 함량은 열처리 온도와 시간에 모두 영향을 받으며 이는 열처리에 따른 비타민 C 햠량의 경향과 유사한 것으로 나타났다. 한편 동일한 열처리 조건에서 비 타민 C와 총 페놀성 화합물의 함량을 비교했을 때, $80^{\circ} \mathrm{C}$ 에 서 5 분 처리 시 총 페놀 함량의 경우 $80.13 \mathrm{mg} \mathrm{GAE} / 100$ $\mathrm{g}$ 으로 대조구에 비해 약 $15 \%$, 비타민 $\mathrm{C}$ 의 함량은 82.47 $\mathrm{mg} / 100 \mathrm{~g}$ 으로 대조구에 비해 약 $32 \%$ 로 감소하였다. 그리고 $90^{\circ} \mathrm{C}$ 에서 5 분 처리 시 총 페놀 함량의 경우 $68.67 \mathrm{mg}$ $\mathrm{GAE} / 100 \mathrm{~g}$ 으로 약 $72.82 \%$, 비타민 $\mathrm{C}$ 의 함량은 22.28 $\mathrm{mg} / 100 \mathrm{~g}$ 으로 약 $18.36 \%$ 정도로 감소하여 다래 퓨레의 비 타민 C는 총 페놀 보다 열에 더 민감하기 때문인 것으로 판단된다. 이러한 페놀성 물질은 대부분의 과채류에 다량 함유되어 있고, phenolic hydroxy기로 인하여 단백질 또는 효소 단백질, 기타 거대분자들과 결합하는 성질, 항산화 효과 그리고 2 가 금속이온과의 결합력을 가지며, 수산기를 통한 수소공여와 페놀 고리구조의 공명 안정화에 의한 항산 화 능력을 나타내는 것으로 보고되었다(71). 과일의 열처리 에 의한 총 페놀 함량에 관한 연구로, Odriozola-Serrano 등(72)은 토마토 주스를 $90^{\circ} \mathrm{C}$ 에서 30 초와 60 초 동안 열처리 한 직후의 총 페놀 함량은 유의적인 차이가 없다고 보고하 였으며, Odriozola-Serrano 등(73)은 딸기 주스를 $90^{\circ} \mathrm{C}$ 에서 30 초와 60 초 동안 열처리한 직후의 총 페놀 함량은 대조구 에 비해서 감소하였다고 보고하였다. 또한 Spanos 등(74)의 연구에서 $80^{\circ} \mathrm{C}$ 에서 15 분 동안 열처리한 사과주스의 경우 총 페놀이 약 $50 \%$ 정도 감소하였다고 보고하였다.

\section{항산화 활성}

열처리 온도 및 시간에 따른 시료의 항산화 활성은 DPPH 라디컬 소거능, ABTS 라디컬 소거능 및 FRAP을 통해서 알아보았고 측정한 결과는 각각 Fig. 5, 6, 7에 나타내었다. $\mathrm{DPPH}$ 라디컬 소거능의 경우 대조구의 $37.78 \%$ 의 소거활성 을 보였고 $1,3,5$ 분 열처리 시 $70^{\circ} \mathrm{C}$ 에서는 각각 $41.22 \%$, $39.93 \%, 39.29 \%$ 로 거의 변화가 없었고, $80^{\circ} \mathrm{C}$ 와 $90^{\circ} \mathrm{C}$ 에서 1 분 처리에서 각각 $41.65 \%, 38.30 \%$ 로 거의 변화가 없었다. $80^{\circ} \mathrm{C}$ 에서 3,5 분과 $90^{\circ} \mathrm{C}$ 에서 3 분 처리 시 각각 $36.70 \%$, $36.10 \%, 36.70 \%$ 로 다소 감소하였으며 $90^{\circ} \mathrm{C}$ 에서 5 분 처리 시 $31.67 \%$ 로 크게 감소하였다. 이는 총 페놀 함량의 열처리 에 따른 경향과 일치하는 것으로 사료된다.

$\mathrm{ABTS}$ 라디컬 소거능의 경우 대조구의 소거활성은 $41.46 \%$ 로 나타났고, 모든 처리 온도에서 1 분간 처리했을 때와 $70^{\circ} \mathrm{C}$ 에서 모든 처리 시간의 소거활성은 $38.30 ~ 42.36 \%$ 의 범위로 대조구와 유사한 활성 보였다. 하지만 $80^{\circ} \mathrm{C}$ 에서 3,5 분과 $90^{\circ} \mathrm{C}$ 에서 3 분 처리 시 $36.10 ~ 36.70 \%$ 의 범위로 열처 리 시간에 따라 다소 감소하였고 $90^{\circ} \mathrm{C}$ 에서 5 분 처리 시 $31.67 \%$ 로 크게 감소하여 다래 퓨레의 열처리에 따른 ABTS 라디컬 소거능의 경우 DPPH 라디컬 소거능과 유사한 경향 으로 나타났다.

$\mathrm{FRAP}$ 의 경우 대조군은 0.79 였으며 모든 온도에서 1,3 분 처리 시 0.71 0.74의 범위로 열처리 시간에 따른 변화는 거의 없었다. 5 분 처리 시 $70^{\circ} \mathrm{C}$ 에서는 0.68 으로 다소 감소하 였고, $80^{\circ} \mathrm{C}$ 와 $90^{\circ} \mathrm{C}$ 에서는 모두 0.58 로 유사한 수치로 크게 감소하였다. 따라서 다래 퓨레의 열처리에 따른 DPPH 라디 컬 소거능과 $\mathrm{ABTS}$ 라디컬 소거능 및 FRAP 모두 열처리 온도가 증가하고 열처리 시간이 길어질수록 항산화능이 감소하는 경향을 공통적으로 가지고, $90^{\circ} \mathrm{C}$ 에서 5 분간 처리 시 활성이 크게 감소하는 것으로 나타났다. 또한 이러한 


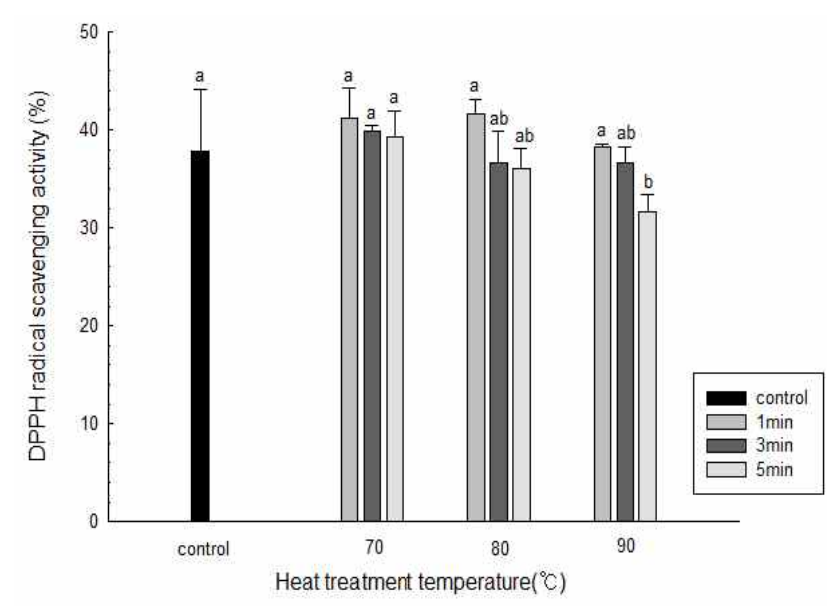

Fig. 5. The effect of heating temperature and time on the DPPH radical scavenging activities of Actinidia arguta puree

Means \pm SD $(n=3)$ in a row followed by same letter are not significantly different by Duncan's multiple range test $(\mathrm{p}<0.05)$.

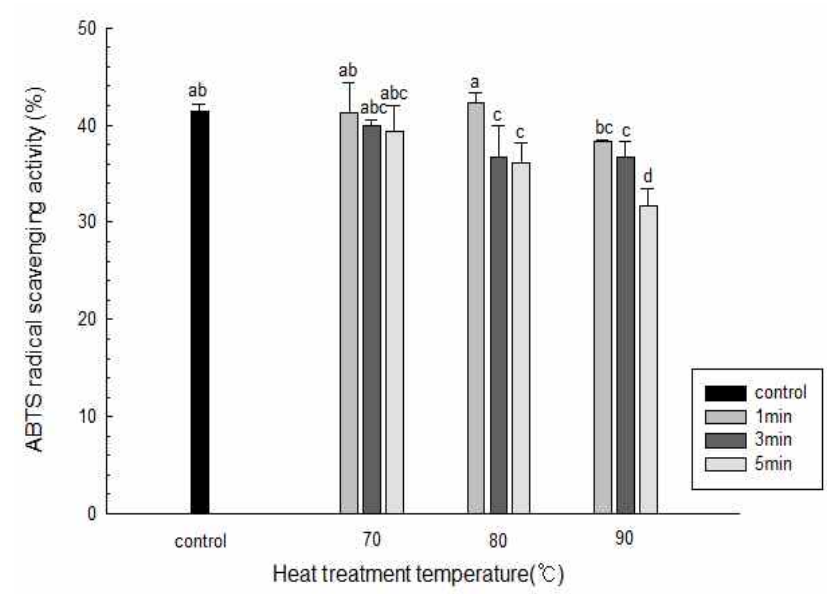

Fig. 6. The effect of heating temperature and time on the ABTS radical scavenging activities of Actinidia arguta puree

Means $\pm S D(n=3)$ in a row followed by same letter are not significantly different by Duncan's multiple range test $(\mathrm{p}<0.05)$.

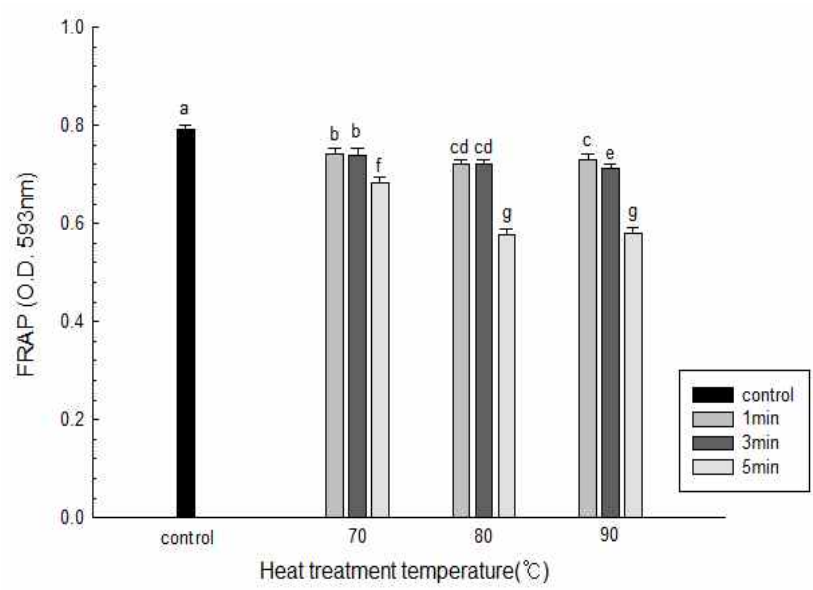

Fig. 7. The effect of heating temperature and time on the FRAP (ferric reducing antioxidant power) of Actinidia arguta puree

Means \pm SD ( $n=3$ ) in a row followed by same letter are not significantly different by Duncan's multiple range test $(\mathrm{p}<0.05)$.
결과는 열처리 조건에 따른 비타민 $\mathrm{C}$ 와 총 페놀 함량의 변화와도 유사한 경향을 보였고 이는 이들 성분이 다래 퓨레의 항산화 활성에 영향을 미치는 주된 인자이기 때문으 로 사료된다. 다래( $A$ arguta)는 높은 항산화활성과 비타민 $\mathrm{C}$ 의 함량으로 인해 매우 유익한 과일이며, 비타민 $\mathrm{C}$ 는 다래 ( $A$ arguta)의 항산화활성에 매우 주요한 역할을 하며(5), 또한 Fisk 등(7)은 페놀성 화합물과 비타민 C는 과일의 항산 화활성에 매우 큰 영향을 미치고, 항산화활성-비타민 $\mathrm{C}$ 함 량, 항산화활성-총 페놀 함량은 각각 매우 큰 상관관계를 가진다고 보고하였다. Scott 등(75)은 과일 주스가 3 가 철을 감소시키는 능력은 총 페놀 함량과 밀접한 관련이 있으며, 이는 페놀의 링 구조에서 hydroxy 그룹의 수소 원자를 공여 에서 기인한다고 보고하였다. 또한 과채류의 총 페놀 및 비타민 $\mathrm{C}$ 의 함량은 항산화활성과 매우 높은 상관관계가 있다고 보고하였다(76-78). 또한 Benlloch-Tinoco 등(79)은 과일의 품질과 안정성을 보장하기 위해서 효소와 미생물을 통제하는 것은 필수적이며, 이를 열처리에 의해서 불활성 화 시킴으로써 개선된 항산화활성을 가지면서, 키위 퓨레 를 안정하게 유지시킬 수 있다고 보고하였다. 결과적으로 다래 퓨레를 적절한 열처리가공을 통해서 항산화활성을 감소시키지 않으면서 이를 안정적으로 유지할 수 있는 조건 을 설정해야 하며, 본 연구에서는 $70^{\circ} \mathrm{C}$ 에서 1 분간 열처리가 가장 효과적인 처리로 사료된다.

\section{요 약}

본 연구는 열처리 온도 및 시간이 토종 다래( $A$ arguta $)$ 퓨레의 품질 특성 및 항산화 활성에 미치는 영향을 알아보 기 위해서 $70,80,90^{\circ} \mathrm{C}$ 의 온도에서 각각 $1,3,5$ 분간 열처리 하여 $\mathrm{pH}$, 당도, pulp 함량, 색도, 점도, 조직감 및 미생물 수 등의 품질특성과 비타민 $\mathrm{C}$, 총 페놀, 항산화 활성을 분석 하였다. $\mathrm{pH}$, 당도 그리고 pulp 함량의 경우 열처리 온도가 증가하고 열처리 시간이 길어질수록 감소하는 경향을 나타 내었고, $\mathrm{L}, \mathrm{a}, \mathrm{b}$ 값과 갈변도는 증가하는 경향으로 나타났으 며, 점도와 adhesiveness 또한 증가하는 경향을 나타내었다. 일반세균과 곰팡이 수는 열처리 온도가 증가하고, 시간이 경과함에 따라 감소하는 경향을 보였다. 대장균군과 효모 는 모든 조건에서 검출되지 않았다. 비타민 $\mathrm{C}$ 와 총 페놀 함량은 온도가 증가하고 열처리 시간이 길어질수록 감소하 는 경향을 나타내었고 $70^{\circ} \mathrm{C}$ 온도에서의 열처리와 모든 열처 리 온도에서 1 분간 열처리 시 대조구와 유사하였고 $90^{\circ} \mathrm{C}$ 에 서 5 분간 처리 시 크게 감소하는 것으로 나타났다. 항산화 활성은 비타민 $\mathrm{C}$ 와 총 페놀 함량과 유사한 결과를 나타내었 고, 따라서 다래의 항산화 활성은 비타민 $\mathrm{C}$ 와 총 페놀이 주요한 요인으로 작용한다고 사료된다. 본 연구의 앞선 결 과를 통해서 다래 퓨레를 $90^{\circ} \mathrm{C}$ 에서 5 분간 열처리 시 이화학 
적 특성과 항산화 활성이 크게 감소하여 품질이 저하되는 것을 확인할 수 있었다. 결과적으로 본 연구 결과는 다래 퓨레의 안정성 및 상품적 가치판단에 따른 기초자료를 제공 할 것으로 사료된다.

\section{감사의 글}

본 연구는 산림청 임업기술개발사업의 '다래를 활용한 건강지향식품 소재 및 가공품 개발'과제(과제번호 : 2013자유10)의 연구비 지원에 의해 수행되었으며 이에 감사드 립니다.

\section{References}

1. Park. YK, Jang YS, Lee MH, Kwon OW (2007) Comparison of antioxidant capacity and nutritional composition of three cultivars of Actinidia arguta. J Korean For Soc, 96, 580-584

2. Hassal AK, Pringle, GJ, Macrae EA (1998) Development, maturation, and postharvest responses of Actinidia arguta (Sieb. et Zucc.) Planch, ex Miq. fruit. N Z J Crop Hort Sci, 26, 95-108

3. Matich AJ, Young H, Allen JM, Wang MY, Fielder S, McNeilage MA, MacRae EA (2003) Actinidia arguta: volatile compounds in fruit and flowers. Phytochem, 63, 285-301

4. Williams MH, Boyd LM, McNeilage MA, MacRae EA, Ferguson AR, Beatson RA, Martin PJ (2003) Development and commercialization of 'baby kiwi' (Actinidia arguta Planch.). Acta Hort, 610, 81-86

5. Okamoto G, Goto S (2005) Juice constituents in Actinidia arguta fruit produced in Shinjo, Okayama. Sci Rep Fac Agric Okayama Univ, Okayama, Japan, 94, 9-13

6. Latocha P, Jankowski P, Radzanowska J (2011) Genotypic difference in postharvest characteristics of hardy kiwifruit (Actinidia arguta and its hybrids), as a new commercial crop Part I. Sensory profiling and physicochemical differences. Food Res Int, 44, 1936-1945

7. Fisk CL, McDaniel MR, Strik BC, Zhao Y (2006) Physicochemical, sensory and nutritive qualities of hardy kiwifruit (Actinidia arguta 'Ananasnaya') as affected by harvest maturity and storage. J Food Sci, 71, 204-210

8. Latocha P (2007) The comparison of some biological features of Actinidia arguta cultivars fruit. Annals of
Warsaw University of Life Sciences-SGGW, Horticulture L/A, 28, 105-109

9. Latocha P, Krupa T (2008) The mineral composition of new genotypes of hardy kiwifruit (Actinidia Lindl.) bred at SGGW. Ann Warsaw Univ of Life Sci-SGGW, Horticulture L/A, 29, 105-110

10. Latocha P, Krupa T, Wolosiak R, Worobiej E, Wilczak J (2010) Antioxidant activity and chemical difference in fruit of different Actinidia sp. Int J Food Sci Nutr, 61, 381-394

11. Nishiyama I, Fukuda T, Oota $T$ (2005) Genotypic differences in chlorophyll, lutein, and $\beta$-carotene content in the fruit of actinidia species. J Agr Food Chem, 53, 6403-6407

12. Nishiyama I, Yamashita Y, Yamanaka M, Shimohashi A, Fukuda T, Oota T (2004) Varietal difference in vitamin $\mathrm{C}$ content in the fruit of kiwifruit and other Actinidia species. J Agr Food Chem, 52, 5473-5475.

13. Ferguson AR, Ferguson LR (2003) Are kiwifruit really good for you?. Acta Hortic, 610, 131-137

14. Kalt W, Forney CF, Martin A, Prior RL (1999) Antioxidant capacity, vitamin $\mathrm{C}$, phenolics and antohcyanins after fresh storage of small fruit. J Agric Food Chem, 47, 4638-4644

15. Kawecki Z, Lojko R, Pilarek B (2007) Malo znane rosliny sadownicze (sittle known orchard plants). Wyd UWM, Olsztyn

16. Leong LP, Shui G (2002) An investigation of antioxidant capacity of fruits in Singapore markets. Food Chem, 76, 69-75

17. Nishiyama I, Yamashita Y, Yamanaka M, Shimohashi A, Fukuda T, Oota T (2004) Varietal difference in vitamin $\mathrm{C}$ content in the fruit of kiwifruit and other Actinidia species. J Agric Food Chem, 52, 5472-5475

18. Rassam M, Laing W (2005) Variation in ascorbic acid and oxalate levels in the fruit of Actinidia chinensis tissues and genotypes. J Agric Food Chem, 53, 2322-2326

19. Matich AJ, Young H, Allen JM, Wang MY, Fielder S, McNeilage MA, Macrae EA (2003) Actinidia arguta : volatile compounds in fruit and flowers. Phytochem, 63, 285-301

20. Fisk CL, McDaniel MR, Strik BC, Zhao Y (2006) Physicochemical, sensory and nutritive qualities of hardy kiwifruit (Actinidia arguta 'Ananasnaya') as affected by harvest maturity and storage. J Food Sci, 71, 204-210

21. Krupa T, Latocha P, Liwinska A (2011) Changes of physicochemical quality, phemolics and vitamin $\mathrm{C}$ 
content in hardy kiwifruit (Actinidia arguta and its hybrid) during storage. Sci Hortic-amsterdam, 130, 410-417

22. Fisk CL, Silver AM, Strik BC, Zhao Y (2008) Postharvest quality of hardy kiwifruit (Actinidia arguta 'Ananasnaya') associated with packaging and storage conditions. Postharvest Biol Technol, 47, 338-345

23. Matich AJ, Young H, Allen JM, Wang MY, Fielder S (2003) Actinidia arguta : volatile compounds in fruit and flowers. Phytochem, 63, 285-301

24. Vicente AR, Martinez GA, Chaves AR, Civello PM (2006) Effect of heat treatment on strawberry fruit damage and oxidative metabolism during storage. Postharvest Biol Technol, 40, 116-122

25. Zhang L, Yu Z, Jiang L, Luo H, Fu L (2011) Effect of post-harvest heat treatment on proteome change of peach fruit during ripening. J Proteomics, 74, 1135-1149

26. McCollum TG, D'Aquino S, McDonald R (1993) Heat treatment inhibits mango chilling injury. Hortsci, 28, 197-198

27. Lurie S, Fallik E, Klein JD (1996) The effect of heat treatment on apple epicuticular wax and calcium uptake. Postharvest Biol Technol, 8, 271-277

28. Cepeda E, García MA, Renobales G, Costell E (2000) Pimento (Capsicum annuum L) puree : preparation, physicochemical properties and microscopical characterisation. J Food Eng, 45, 85-92

29. Kwon GM, Kim JW, Youn KS (2013) Effect of different pre-treatments on the physicochemical and antioxidant activities of cold-vacuum dried peaches. Korean J Food Sci Technol, 45, 466-472

30. Jeong CH, Lee WJ, Bae SH, Choi SG (2007) Chemical components and antioxidative activity of Korean gold kiwifruit. J Korean Soc Food Sci Nutr, 36, 859-865

31. Kim DO, Jeong SW, Lee CY (2003) Antioxidant capacity of phenolic phytochemicals from various cultivars of plums. Food Chem, 81, 321-326

32. Choi JS, Lee JH, Park HJ, Kim HG, Young HS, Mun SI (1993) Screening for antioxidant activity of plants and marine algae and it's active principle from Prunus davidiana. Kor J Pharmacogn, 24, 299-302

33. Foroogh B, Abbas FMA, Azhar ME (2008) Antioxidant activity and phenolic content of various date palm (Phoenix dactylifera) fruits from Iran. Food Chem, 107, 1636-1641

34. Aguilar-Rosas SF, Ballinas-Casarrubias ML, Nevarez-Moorillon GV, Martin-Belloso O, Ortega-Rivas
E (2007) Thermal and pulsed electric fields pasteurization of apple juice effects on physicochemical properties and flavour compounds. J Food Eng, 83, 41-46

35. Jang KW, Hur JK, Kim SK, Haek YJ (1996) Effects of pasteurization and storage temperatures on the quality of orange juice. Korean J Food Sci Technol, 28, 8-14

36. Rossi M, Giussani E, Morelli R, Scalzo RL, Nani RC, Torreggiani D (2003) Effect of fruit blanching on phenoilcs and radical scavenging activity of highbush blueberry juice. Food Res Int, 36, 999-1005

37. Liu Y, Hu X, Zhao X, Song H (2012) Combined effect of high pressure carbon dioxide and mild heat treatment on overall quality parameters of watermelon juice. Innova Food Sci Emerg Technol, 13, 112-119

38. Biansheng Li, Wei Z, Canhui M (2010) Comparison of effects of ultra-high pressure and heat sterilization on qualities of freshly-squeezed pineapple juice, Trans Chinese Soc Agric Eng, 26, 359-364

39. Lee MK (1998) Enzymatic determination of glucose using soybean sprouts peroxidase. Korean J Life Sci, 8, 416-420

40. Park HO (1996) A study of pectinesterase polygalacturonase,lipoxygenase and peroxidase in hot pepper. Korean J Food Nutr, 9, 52-58

41. Lee K, Kim KH, Kim HK (2002) Thermal inactivation parameters of peroxidase in Flammulina velutipes and Lyophyllum ulmarium. Korean J Food Sci Technol, 34, 1067-1072

42. Kweon HJ, Kim MJ, Lee J, Choi C, Tae, Yoon TM, Kang IK (2012) Effects of aminoethoxyvinylglycine application and heat treatment on fruit quality of 'Fuji' apples during CA storage. Korean J Hort Sci Technol, 30, 527-533

43. Ahmed J, Shivshare US, Raghavan GSV (2000) Rheological characteristics and kinetics of colour degradation of green chilli puree. J Food Eng, 44, 239-244

44. Song JY, An GH, Kim CJ (2003) Color, texture, nutrient contents, and sensory values of vegetable soybeans [Glycine max (L.) Merrill] as affected by blanching. Food Chem, 83, 69-74

45. Gunawan MI, Barringer SA (2000) Green color degradation of blanched broccoli (Brassica oleracea) due to acid and microbial growth. J Food Process Pres, 24, 253-263

46. Lee $H$ (1995) The measurement methods of the textural characteristics of fermented vegetables. Korean J Soc Food Sci, 11, 83-91 
47. Beirão-da-Costa S, Steiner A, Correia L, Empis J, Moldão-Martins M (2006) Effects of maturity stage and mild heat treatments on quality of minimally processed kiwifruit. J Food Eng, 76, 616-625

48. Lee JW, Kim IW, Lee KW, Rhee C (2003) Effects of pasteurization and storage temperatures on the physicochemical characteristics of kiwi juice. Korean $\mathbf{J}$ food Sci Technol, 35, 628-634

49. Koca N, Karadeniz F (2005) Effect of pH on chlorophyll degradation and colour loss in blanched green peas. Food Chem, 100, 609-615

50. Canjura FL, Schwartz SJ, Nunes RV (1991) Degradation kinetics of chlorophylls and chlorophyllides. J Food Sci, 56, $1639-1643$

51. Lin Z, Schyvens EJ (1995) Influence of blanching treatments on the texture and color of some processed vegetables and fruits. J Food Process Pres, 19, 451 - 465

52. Lo' pez-Ayerra B, Murcia MA, Garc1'a-Carmona F (1998) Lipid peroxidation and chlorophyll levels in spinach during refrigerated storage and after industrial processing. Food Chem, 61, $113-118$

53. Schwartz SJ, Lorenzo TV (1991) Chlorophyll stability during continuous aseptic processing and storage. J Food Sci, 56, 1059 - 1062

54. Tárrega A, Del Carmen Gurrea M, Navarro JL, Carbonell JV (2013) Gelation of persimmon puree and its prevention by enzymatic treatment. Food Biopro Technol, 6, 2399-2405

55. Christensen SH (1986) Pectins. Food Hydrocolloids, 3, 205-230

56. Rolin C (1993) Pectin. In : Industrial Gums Polysaccharides and Their Derivatives (3rd Ed.), Whistler RL, BeMiller JN (Editor), Academic Press, New York, p $257-293$

57. Galanakis CM, Tornberg E, Gekas V (2010). The effect of heat processing on the functional properties of pectin contained in olive mill wastewater. LWT-Food Sci Tech, 43, $1001-1008$

58. Gould WA (1991) Tomato Production, Processing and Technology (3rd). CTI Publications Inc, Maryland, Baltimore, USA, p 201-217

59. Kim TH, Yun HJ, Park KG, Hong EK, Kim SR, Kim WN, Yun JC, Hong MK, Ryu KY (2011) Effects of improved heat treatment on microbial reduction and germination in sprout vegetable seeds. Korean J Food Sci, 43, 611-617

60. Lee YK, Jun SY (2014) Effects of heat treatments on the microbial reduction and germination rates of red radish sprout seeds (Raphanus sativus). Korean J Food Preserv, 21, 544-548

61. Lurie S (1998) Postharvest heat treatments. Postharvest Biol Technol, 14, $257-269$

62. Paull RE, Chen NJ (2000) Heat treatment and fruit ripening. Postharvest Biol Technol, 21, 21-37

63. Vincente AR, Martinez GA, Civello PM, Chaves AR (2002) Quality of heat-treated strawberry fruit furing refrigerated storage. Postharvest Biol Technol, 25, 59-71

64. Garc'ia JM, Aguilera C, Jim'enez AM (1996) Gray mold in and quality of strawberry fruit following postharvest heat treatment. HortSci, 31, $255-257$

65. Yeom HW, Streaker CB, Zhang QH, Min DB (2000) Effects of pulsed electric field on the quality of orange juice and comparison with heat pasteurization. J Agri Food Chem, 48, 4597-4605

66. Smooth JH, Nagy S (1942) Temperature and storage effects on percent retention and percent $U$. S. recommended dietary allowance of vitamin $\mathrm{C}$ in canned single-strength orange juice. J Agric Food Chem, 25, 135-141

67. Sánchez-Moreno C, Plaza L, Ancos B, Pilar Cano M (2006) Impact of high-pressure and traditional thermal processing of tomato pur'ee on carotenoids, vitamin C and antioxidant activity. J Sci Food Agr, 86, 171-179

68. Spark AA (1969) Role of amino acid in non-enzymatic browning. J Sci Food Agric, 20, 308-315

69. Sadler GD, Parish ME, Wicker L (1992) Microbial, enzymatic and chemical changes during storage of fresh and processed orange juice. J Food Sci, 51, 1187-1193

70. Lodge N (1981) Two novel processed products. Food Technol, 16, 34-40

71. Jeong SM, Son MH, Lee SC (2003) A survey on contents of phenolic compounds of market fruit and vegetables juices. J Basic Sci, 18, 117-123

72. Odriozola-Serrano I, Soliva-Fortuny R, Hernández-Jover T, Martín-Belloso O (2009) Carotenoid and phenolic profile of tomato juices processed by high intensity pulsed electric fields compared with conventional thermal treatments. Food Chem, 112, 258-266

73. Odriozola-Serrano, Soliva-Fortuny R, Martín-Belloso O (2008) Phenolic acids, flavonoids, vitamin C and antioxidant capacity of strawberry juices processed by high-intensity pulsed electric fields or heat treatments. Eur Food Res Technol, 228, 239-248

74. Spanos GA, Wrolstad RE (1992) Phenolic of apple, pear 
and white grape juices and their changes with processing and torage - a review. J Agric Food Chem, 40, 1478-1487

75. Scott G (1997) Antioxidants in science, technology, medicine and nutrition. Albion Publishing, Chichester, England, p 80-92

76. Stewart AJ, Bozonnet S, Mullen W, Jenkins GI, Lean MEJ Crozier A (2000) Occurrence of flavonols in tomatoes and tomato-based products. J Agric Food Chem, 48, $2663-2669$

77. Gardner PT, White TAC, McPhail DB, Duthie GG (2000) The relative contributions of Vitamin $\mathrm{C}$, carotenoids and phenolics to the antioxidant potential of fruit juices. Food
Chem, 68, $471-474$

78. Prior RL, Cap G, Martin A, Sofic E, McEwen J, O'Brien C, Lischner N, Ehlenfeldt M, Kalt W, Krewer G, Mainland CM (1998) Antioxidant capacity as influenced by total phenolic and anthocyanin content, maturity, and variety of Vaccinium species. J Agric Food Chem, 46, $2686-2693$

79. Benlloch-Tinoco M, Igual M, Rodrigo D, MartínezNavarretea N (2013) Comparison of microwaves and conventional thermal treatment on enzymes activity and antioxidant capacity of kiwifruit puree. Innova Food Sci Emerg Technol, 19, 166-172 